\title{
HVORFOR ER FELTET SEKSUELLE OVERGREP MOT BARN PREGET AV STEREOTYPE OPPFATNINGER?
}

\author{
Av DR. PHILOS Elisiv BAKKETEIG*
}

\begin{abstract}
In this paper I propose three explanations for why stereotypes tend to develop with reference to child sexual abuse. First, stereotyped understandings provide us with a certain distance and thereby protect us from the painfull knowledge and images of child sexual abuse. Second, stereotypes create a comfortable distance between "normality" and abuse. Recognition of the "normality" of abuse might otherwise result in a threatening demand for fundamental changes in gender and power relations. Third, stereotyped understandings result from the unusually heated controversies surrounding the debate on child sexual abuse. **
\end{abstract}

På feltet seksuelle overgrep mot barn hersker en rekke stereotype forestillinger. Disse knytter seg til omfanget av seksuelle overgrep mot barn, til barn som utsettes for seksuelle overgrep, til barnas mødre og til overgriperne. Stereotypiene har ikke alltid eksistert samtidig, og ulike forestillinger har preget debatten til ulike tider. En stereotypi kan defineres som en inngrodd eller vanemessig oppfatning eller forestilling. På feltet seksuelle overgrep mot barn eksisterer det en rekke forestillinger som kan betegnes som stereotypier. For det første er det forestillingen om at alle personer som begår seksuelle overgrep mot barn er såkalt pedofile. Begrepet pedofili brukes i mange forskjellige betydninger. I henhold til den amerikanske psykiatriforeningens diagnosemanual (DSM) defineres pedofile som personer som begår:

«[h]andlinger eller [har] fantasier om å engasjere seg i seksuell aktivitet med barn under pubertetsalder, enten som den eneste måten å oppnå seksuell tilfredsstillelse eller som den mest vanlige måten å oppnå slik tilfredstillelse.» (DSM-III 302.20)

I den alminnelige debatt brukes imidlertid betegnelsen pedofili ofte om alle som begår seksuelle overgrep mot barn. Samtidig assosieres begrepet med en person som ikke kan styre sine seksuelle drifter. Hanne Kolterud Skiaker (1998) viser for eksempel i sin mellomfagsoppgave i kriminologi, hvordan denne forståelsen av pedofili var med å skape et monsterbilde av barneovergripere i mediedebatten som fulgte i kjølvannet av den såkalte Belgia-saken sommeren og høsten 1998. Belgia-saken omhandlet bortføring og seksuelle overgrep mot fire

\footnotetext{
* Artikkelen bygger på forfatterens prøveforelesning for dr.philos-graden holdt i juni 2000. En spesiell takk rettes til Ragnhild Hennum og Jane Dullum for fine innspill og kommentarer til manus. Takk også til Sidsel Nyhagen for korrekturlesning.

** Title in English: Why is our Understanding of Sexual Assaults against Children Characterised by Stereotypes? Original in Norwegian.
} 
jenter i alderen 8-12 år, begått av en 39 år gammel mann som tidligere var dømt for seksuelle overgrep mot barn. To av jentene ble funnet omkomne (ibid. s. 3). Skiaker viser hvordan den etterfølgende debatten var preget av krav om strengere straffer, og hvor pedofile ble fremstilt som en betydelig risikofaktor i samfunnet. Oppfatningen av overgripere som pedofile, står i kontrast til unders $\emptyset$ kelser som viser at det ikke er slik at alle som begår seksuelle overgrep er pedofile. Det står også i kontrast til at personer som er såkalt pedofile ikke nødvendigvis begår seksuelle overgrep mot barn.

Et annet spørsmål det hersker ensidige og stereotype oppfatninger om, er hvorvidt man kan stole på barn som forteller om seksuelle overgrep. Hennum (1999) oppsummerer forskningen rundt dette spørsmålet slik at man ikke kan svare ja eller nei på dette spørsmålet. I utgangspunktet kan man ikke stole verken mer eller mindre på fornærmede i saker om seksuelle overgrep enn i andre typer straffesaker (ibid. s. 172). I kontrast til dette utgangspunktet, står langt mer entydige standpunkter om hvorvidt man kan stole på det barn forteller. På den ene siden er det blitt fremholdt at barn sjelden eller aldri lyver om seksuelle overgrep. På den andre siden finner en de som hevder at barn er svært fantasifulle og påvirkelige, og at man ikke kan stole på det barn forteller om seksuelle overgrep. Tidligere var det særlig i forhold til tenåringsjenter at det ble fremholdt at risikoen for falske påstander om seksuelle overgrep var stor (se Grothe Nielsen 1992 s. 92 og Hennum 1999 s. 160). Selv om oppfatningen av troverdigheten til barn som forteller om seksuelle overgrep nok er blitt mer nyansert i de senere år, illustrerer de ulike oppfatningene tendensen til ensidige forestillinger om barna.

Falske overgrepminner blant voksne kvinner er et annet omdiskutert tema. Særlig i USA har denne problematikken vært tema i et stort antall artikler. Debatten gjelder kvinner som i voksen alder gjennom terapi husker overgrepminner fra de var barn, men som de mener har vært fortrengt i deres bevissthet. På feltet har det lenge pågått en diskusjon om hvorvidt slike overgrepminner er reelle. På den ene siden står kvinnene og deres terapeuter som hevder at overgrepminnene er uttrykk for reelle opplevde hendelser. På den andre siden står de som hevder at overgrepminnene er falske, og et resultat av påvirkning fra terapeutenes side. Forskningen om fortrengte overgrepminner viser på sin side at både fortrengning av og falske minner om seksuelle overgrep kan forekomme. En annen utbredt oppfatning er at mødre til barn som mistenkes utsatt for seksuelle overgrep, konstruerer falske anmeldelser om incest i den hensikt å vinne i en konflikt med barnets far om hvem som skal ha omsorg og samvær med barna. Denne oppfatningen står i kontrast til undersøkelser som viser mødre som er tilbakeholdne, forsiktige og viser en sterk motstand mot å fremstille sin tidligere ektefelle som overgriper (Mossige 1998 s. 239).

Det fremholdes videre at barnevernet "ser overgrep overalt" og reiser mistanke om seksuelle overgrep mot barn i saker hvor det ikke er grunnlag for det. Det 
foreligger ikke dokumentasjon for denne påstanden. Det kan være at barnevernet ser flere tilfeller av seksuelle overgrep mot barn enn det som det er grunnlag for. Det kan også være at barnevernet har saker, men ikke ser seksuelle overgrep der de faktisk foregår. Det finnes eksempler på begge disse situasjonene. Men fordi vi ikke kjenner det faktiske omfanget av seksuelle overgrep der barnevernet er involvert, blir påstanden om at barnevernet ser overgrep overalt udokumentert, og i tillegg umulig å dokumentere. Til tross for at påstanden ikke er dokumentert, lever den likevel videre i debatten om seksuelle overgrep mot barn. Det er videre grunn til å understreke at det ligger i barnevernets virksomhet å beskytte barn mot seksuelle overgrep, slik at de skal være oppmerksom på muligheten for at barnet kan være utsatt for overgrep.

De stereotypiene som jeg har trukket frem, finner en igjen både i deler av faglitteraturen på feltet, i offentlige dokumenter som berører seksuelle overgrep mot barn, og i den alminnelige samfunnsdebatten. At oppfatningene finnes igjen på flere arenaer betyr imidlertid ikke at de kommer til uttrykk i samme utstrekning på de ulike arenaene. I hvilken grad de finnes, og i hvilken grad de kommer til uttrykk har sammenheng med blant annet den kunnskapen som foreligger på de ulike arenaene. Det er også grunn til å tro at grad av konkret berøring med overgrepsproblematikken kan ha betydning for i hvor stor grad man er bærere av stereotype forestillinger.

Noen vil kanskje hevde at disse stereotypiene ikke lenger finnes, at et høyere kunnskapsnivå har bidratt til å nyansere feltet. Fra midten av 80-tallet har kunnskapsutviklingen på feltet vært stor. Det er liten tvil om at samfunnets satsning på mer kunnskap har bidratt til å nyansere debatten på feltet seksuelle overgrep mot barn. Flere nyanser er imidlertid ingen garanti mot at stereotypier og ensidige forestillinger fortsatt består. En undersøkelse som belyser dette er gjennomført av Margareta Hallberg og Eva Marie Rigné. Disse har gjort en undersøkelse av debatten om seksuelle overgrep i Sverige i perioden 1994-1998. De finner at de grunnleggende kontroversene består, til tross for mer forskning, mer kompetanse og et bedre utbygget apparat for å håndtere disse sakene (Hallberg og Rigné 1999 s. 5). For eksempel gjelder dette spørsmålet om troverdigheten av barns fortellinger. Kontroversene har imidlertid spredt seg til andre aktører enn de som deltok i debatten tidligere, og der både ulike profesjoner, akademikere og organisasjoner deltar i debatten. Aktørenes standpunkter har imidlertid i liten eller ingen grad blitt påvirket av det forløp som kontroversene har hatt (ibid.). Deres undersøkelse kan sånn sett tale for at ensidige forståelser fortsatt består til tross for den kunnskapsproduksjon som har funnet sted fra midten av 1980-tallet og frem til i dag.

\section{Det sykliske mønsteret på feltet}

Som nevnt innledningsvis, er det ikke slik at disse stereotypiene alltid har eksistert på samme tid. Oppmerksomheten rundt seksuelle overgrep mot barn har 
vekslet mye. I det følgende skal jeg belyse hvordan oppmerksomheten og debatten rundt seksuelle overgrep mot barn har skiftet over tid. Erna Olafson, David L. Corwin og Roland Summit (1993) har belyst oppmerksomheten rundt seksuelle overgrep mot barn i løpet av de siste 150 år i USA og i Europa (se også Myers 1994 s. 21-23).

I denne redegjørelsen foretar forfatterne en detaljert gjennomgang av feltet gjennom ulike perioder. Den første perioden de belyser, starter på midten av 1800-tallet og varer frem til Freud kom med sin forførelsesteori i 1896. I denne perioden fantes ingen undersøkelser av omfanget av seksuelle overgrep mot barn, men gjennom anekdotiske kilder, rettsdokumenter og folklore, fremgår det at seksuelle overgrep mot barn var utbredt både i England og USA. For eksempel trekker forfatterne frem at i perioden 1730 til 1789 omfattet en fjerdedel av voldssakene i Old Baley voldtekt mot barn under 10 år (ibid. s. 8). I denne perioden ble seksuelle overgrep mot barn oppfattet som et fattigdomsproblem, og der forklaringen på forekomsten var fattigdom, trangboddhet og promiskuitet i de lavere sosiale klasser. Dersom påstander om overgrep ble fremsatt fra personer som ikke tilhørte de lavere sosiale klasser, ble overgrephistorier fortolket som løgnaktige og et utslag av ofrenes fantasi. Men allerede i 1856 ble dette synet imøtegått. I et fransk medisinsk tidskrift ble det fremhevet at seksuelle overgrep mot barn var utbredt, at overgrep ofte ikke satte fysiske spor, at barnas historier ofte var sanne og at seksuelle overgrep ikke var et problem som utelukkende forekom i lavere sosiale klasser. I tillegg ble det fremhevet at overgrep ofte ble begått av fedre og brødre av barnet. Oppfatningen av seksuelle overgrep mot barn som et utslag av løgnaktige påstander og som et fenomen som forekom i de lavere sosiale klasser, fortsatte likevel å dominere det almene synet på seksuelle overgrep mot barn. Åsa Bergenheim er en annen forfatter som har belyst synet på seksuelle overgrep i denne perioden. Hun viser til rettsmedisineren Brouardel som mente at falske anklager om seksuelle overgrep mot barn var svært utbredt. Han trakk blant annet frem at barn og foreldre i fellesskap konstruerte overgrep i den hensikt å skade en annen person (1998 s. 19). Med andre ord ser en at flere av de temaene som diskuteres i dag var gjenstand for diskusjon for 150 år siden.

Den neste perioden som Olafson, Corwin og Summit belyser, knytter seg til Freud $\mathrm{og}$ hans forførelsesteori. Freud rettet fokus mot seksuelle overgrep som en mulig forklaring på hysteri. Der medisinere tidligere hadde fortolket kvinners historier som løgner, reiste Freud spørsmålet om de historiene som ble fortalt faktisk kunne være sanne. Han fremhevet blant annet den tilbakeholdenheten pasientene viste og den skamfølelsen pasientene formidlet når de fortalte om seksuelle overgrep. Han fremhevet også at incest var utbredt - også i respektable familier. Dette innebærer at Freud i første omgang imøtegikk mange av de oppfatningene om seksuelle overgrep mot barn som hadde hersket tidligere. Senere skiftet imidlertid Freud mening. Overgrephistoriene ble i stedet tilskre- 
vet fantasier hos kvinnene. Flere forklaringer har vært trukket frem for at han skiftet mening. En av dem er at det ble for belastende for ham å opprettholde de fortolkningene som han først hadde fremmet. I følge Åsa Bergenheim begrunnet Freud selv skiftet med at det var usannsynlig at så mange biologiske fedre skulle være overgripere. Dette var usannsynlig blant annet fordi overgrepanklagene også omfattet formuende og moralsk uklanderlige menn (1998 s. 25). Freuds oppfatning av kvinners historier som et utslag av fantasier fikk stor gjennomslagskraft. Etter Freuds avvisning av overgrephistoriene som fantasier, ble seksuelle overgrep mindre aktuell som en forklaring for traumatiske lidelser.

Den siste perioden som Olafson, Corwin og Summit belyser, knytter seg til perioden fra 1970-årene og opp mot 1990 da feministenes innsats med å sette seksuelle overgrep mot barn i fokus fikk gjennomslag. Denne perioden var preget av stor mediaoppmerksomet og stor forskningsaktivitet. Blant annet ble det gjennomført et stort antall undersøkelser som belyser omfanget og skadevirkninger av seksuelle overgrep mot barn. Videre var denne perioden preget av et sterkt fokus på kompetanseutvikling innen ulike profesjoner, og utbygging av et apparat til å håndtere disse sakene. Denne perioden var også kjennetegnet av et sterkt offerorientert perspektiv.

På slutten av åttitallet fremhever forfatterne at det kom et backlash eller tilbakeslag hvor fenomenet igjen ble trukket i tvil. Påstander om at seksuelle overgrep mot barn er overrapportert, et utslag av fabrikkerte anklager og at feltet er preget av en overreaksjon, fikk igjen en sentral plass i debatten om seksuelle overgrep mot barn. En mer kritisk holdning til seksuelle overgrep har blant annet ført til et sterkere fokus på rettsikkerheten til personer som anklages for å ha begått slike overgrep. Oppmerksomheten rundt seksuelle overgrep mot barn er heller ikke like sterk som den var på midten av 1980-tallet.

Fokuseringen av seksuelle overgrep mot barn har med andre ord vekslet i ulike perioder, og ulike syn på overgrep har preget de ulike periodene. Samtidig er det verdt å merke seg at de samme temaene og kontroversene kommer igjen i de ulike periodene. Dette kan tyde på at det har pågått en kamp om definisjonsmakten med hensyn til å se seksuelle overgrep mot barn som en sosial realitet.

\section{Hvorfor er feltet preget av stereotypier og hva er drivkraften bak dem?} Motstand mot smertefull kunnskap

Tendensen til stereotype forestillinger kan ha flere mulige forklaringer. Den kan for det første uttrykke et behov for å forenkle og skape oversiktlighet i noe som $\mathrm{i}$ utgangspunktet er uforståelig - at voksne kan begå seksuelle overgrep mot barn. En kan altså se stereotypiene som et forsvar mot smertefull kunnskap. Det smertefulle i å erkjenne at voksne begår seksuelle overgrep mot barn, gir et behov for å skape avstand. Ved å se personer som begår seksuelle overgrep som pedofile, skapes et skille mellom dem og oss. De pedofile er de som er annerledes enn oss - syke og avvikende personligheter. Når overgriperen er den pedofile slipper 
man å tenke den ubehagelige tanken at fedre, onkler, brødre eller bestefedre kan begå seksuelle overgrep mot barn. I tillegg vil en rekke av de stereotypiene som svekker troverdigheten i fremsatte overgrepanklager kunne redusere ubehaget. Ved å fremstille anmeldelser fra mødre som falske, skapes tvil om fenomenets omfang. ' Tvil om fenomenets omfang skapes også når barnevernet oppfattes som en kontrollinstitusjon som ser overgrep overalt. Det samme gjør forståelsen av falske overgrepminner fra voksne overgreputsatte. Når omfanget ikke er så stort, vil en tenke at seksuelle overgrep bare rammer noen få barn. Når overgrep bare rammer noen få, trenger man ikke å tenke så mye på det. Det er en måte å gjøre den ubehagelige tanken om at barn utsettes for seksuelle overgrep mindre invaderende fordi barn som hovedregel ikke vil oppleve seksuelle overgrep. Stereotypiene kan på denne måten sees som uttrykk for motstand mot å se seksuelle overgrep mot barn som et reelt problem.

En slik motstand må sees i sammenheng med at kunnskap om seksuelle overgrep mot barn er tabuisert kunnskap. Det tabuiserte ved seksuelle overgrep mot barn kan belyse hvorfor det foreligger en motstand mot kunnskap om seksuelle overgrep mot barn. Halldis Leira beskriver et tabu som et kulturelt imperativ. Tabu er i følge Leira: “...et sosialt forbud mot å synliggjøre, eller [å] fortelle." Hun hevder videre at: "Kulturen opprettholder sine tabuer i forakt som en mulig truende sanksjon. Den som trosser forbudet mot å synliggjøre, kan bli påført forakt og dermed mulig skam." I følge Leira vil vi forsøke å unngå en slik følelse av skam. "Derfor underordner vi oss normen om at det usynlige fortsatt ikke skal bli sett." (ibid. s. 60).

Harriet Holter (1992) fremhevet at nettopp tausheten kan være en kilde til økt forståelse. Hun hevdet at innsikt i seksuelle overgrep mot barn måtte tilegnes nettopp gjennom å utforske "selve tausheten som sosial og kulturell prosess" (ibid. s. 24).

Noen vil kanskje innvende at seksuelle overgrep mot barn i de siste årene ikke har vært et taushetsbelagt tema. Noen vil hevde at temaet tvert imot er blitt snakket i hjel. Holter betegner imidlertid offentligheten rundt seksuelle overgrep mot barn som en pseudo-offentlighet (ibid). Tausheten er brutt, men dette er likevel overgrep en ikke vil forholde seg til. Selv om seksuelle overgrep mot barn fokuseres i offentligheten, ligger det tabuiserte rundt seksuelle overgrep mot barn fortsatt der som et grunnleggende premiss.

Kanskje kommer det tabuiserte ved seksuelle overgrep mot barn til uttrykk på en annen måte i dag enn tidligere. Man kan ikke lenger benekte at seksuelle overgrep mot barn finner sted - og at det har et visst omfang. Isteden kommer det tabuiserte ved handlingene til uttrykk i forhold til beskrivelsen av fenomenet. Vi ønsker at den som begår seksuelle overgrep mot barn skal være mannen med frakk og godterier i parken - fjernt fra det som kjennetegner den "normale", velfungerende familiefaren. Dette innebærer at selv om det nå aksepteres at visse former for seksuelle overgrep mot barn finner sted, er det noen former for 
seksuelle overgrep man fortsatt ikke ønsker å se. Med andre ord er det fortsatt slik at det tabuiserte ved handlingene påvirker vår måte å forholde oss til fenomenet seksuelle overgrep mot barn.

Dersom det er slik at de ensidige forståelsene kan sees som et forsvar mot smertefull kunnskap, er det nærliggende å tenke seg at allmennheten bare klarer å ta imot litt av denne kunnskapen av gangen. Blir ubehaget for sterkt, kan dette føre til at oppmerksomheten rundt feltet som sådan blir mindre fordi ubehaget fører til at en går trett av å høre om seksuelle overgrep mot barn. David Finkelhor (1994) anfører en slik forklaring for hvorfor oppmerksomheten rundt feltet seksuelle overgrep mot barn har vært mindre i perioder. En slik tretthet inngår i følge Finkelhor som en naturlig del av den syklus som alle sosiale bevegelser følger (1994 s.1).

\section{Motstand mot uønsket eller farlig kunnskap}

Det trenger imidlertid ikke bare være ubehaget ved tanken om at voksne har sex med barn som gir grunnlag for stereotype oppfatninger. Seksuelle overgrep mot barn berører grunnleggende spørsmål om makt, seksualitet og undertrykking. Samtidig har menn tradisjonelt hatt undertrykkerens rolle og kvinner og barn har hatt de undertryktes rolle. En forklaring er at den oppmerksomheten som har vært rettet mot seksuelle overgrep mot barn, har representert en trussel mot etablerte maktstrukturer i samfunnet. Trusselen mot maktstrukturene har ført til en motstand som har bidratt til å undertrykke fokus på seksuelle overgrep. Olafson, Corwin og Summit fremsetter en slik forklaring når de belyser hvorfor oppmerksomheten rundt seksuelle overgrep har vært redusert i perioder:

\footnotetext{
"If we were really to take into account the role sexual coercion and violence play in shaping human culture and personal identity, fundamental structures of thought could well be shaken and changed. Such great shifts in world view unsettle even those whose privileges and self-images are not directly threatened by them." (Olafson, Corwin og Summit 1993 s. 19).
}

Det kan være slik at seksuelle overgrep mot barn gjør en oppmerksom på trekk ved den "vanlige" kjønnskulturen og at denne gjenkjennelsen skaper et ubehag. Gjenkjennelsen kan gi opphav til grunnleggende spørsmål om fordeling av makt mellom kjønnene. For å unngå en slik gjenkjennelse blir det behov for å skape avstand mellom overgrep og "normalitet". Det blir behov for å trekke frem bilder av for eksempel overgriperen som veldig annerledes enn den vanlige familiefaren, fordi man ellers ville måtte stille spørsmålstegn ved om det er forhold ved kjønnskulturen som gjør slike overgrep mulige. Høigård fremholder en slik forklaring i en kronikk i Aftenposten (Høigård 1996). Hun fremholder der at myten om den pedofile har til hensikt å skape brudd og diskontinuitet i den forstand at den skaper en bekvem avstand til vår egen seksuelle kultur. Motstand mot å problematisere og endre grunnleggende maktforskjeller mellom kjønnene 
kan derfor også være en mulig forklaring på hvorfor forståelsene på feltet blir ensidige og stereotype. Denne forklaringen kan en betegne som et forsvar mot uønsket eller farlig kunnskap.

Erfaringene til de personene som arbeider på feltet seksualisert vold kan indikere at kunnskap om seksuelle overgrep anses som uønsket eller farlig. Karin Widerberg (1995) fremholder for eksempel at kulturens tabu knyttet til seksuelle overgrep mot barn lukter, og at denne lukten eller odøren kleber også ved de som arbeider på feltet som forskere og som hjelpere (ibid. s. 87). Dette fører til at forskere på andre felt fornekter forskningen om seksualisert vold - med andre ord at de ikke vil bruke denne forskningen. Hun mener at årsaken til dette kan være at: “...man vill att verkligheten ska vara en annan, att kvinnor og män ska vara något annat” (ibid. s. 87). Her berører Widerberg etter mitt skjønn et grunnleggende trekk ved flere av de forklaringene jeg trekker frem: Ønsket om at verden skal se annerledes ut. Dette ønsket gir seg på ulike måter utslag i strategier for å opprettholde et bilde av virkeligheten som ligger innenfor det hver enkelt av oss kan bære.

\section{Stereotypier skapt av kontroverser på feltet}

Den siste forklaringen jeg skal trekke frem er at kontroversene på feltet i seg selv er med å skape ensidige og stereotype oppfatninger. Denne forklaringen omfatter for det første ensidige oppfatninger som en følge av et behov for å forsvare seg mot motstanden mot kunnskap på feltet. Mens de foregående forklaringene har belyst argumenter til personer som av ulike grunner ikke vil se seksuelle overgrep mot barn, kan de som vil se seksuelle overgrep mot barn, også være med å skape ensidige og stereotype forståelser.

De som fremholder at barn aldri lyver om seksuelle overgrep, gir ikke uttrykk for en motstand mot å se seksuelle overgrep. Påstanden om at barn aldri lyver om seksuelle overgrep kan heller sees som et forsvar mot den samfunnsmessige motstanden mot å se seksuelle overgrep mot barn. Man ønsker at seksuelle overgrep mot barn skal tas på alvor og ikke gjøres til gjenstand for fortielse. En kan tenke seg at det som trekker i retning av å undertrykke oppmerksomheten skaper behov for et forsvar mot at kunnskapen og interessen for feltet igjen reduseres. Man må motvirke at fenomenet ugyldiggjøres, reduseres og minimaliseres. Dette fører til behov for bevisførsel for fenomenets eksistens og utrykksform - og for å ta i bruk en forsterket retorikk for å holde fokus på fenomenet. En forsterket retorikk kan være med på å skape og forsterke ensidige forståelser på feltet. Påstanden om at barn aldri lyver om seksuelle overgrep, kan sees i en slik sammenheng. Fordi noen fremholder at barn lyver, føler andre seg tvunget til å bevise det motsatte ved å hevde at barn aldri lyver. Mange av debattantene ville kanskje vært mer nyanserte i sine uttalelser dersom feltet ikke hadde vært preget av så sterke motstridende synspunkter. Slik det er i dag kan det være at noen av debattantene tenker at dersom jeg sier at "jo det forekommer en sjelden 
gang at barn lyver, men stort sett lyver de ikke" da ville dette bli tatt til inntekt for at barn lyver. Fordi vedkommende ikke ønsker å bli tatt til inntekt for at barn lyver, velger han eller hun det mer bastante standpunktet "barn lyver aldri". Slik kan begge sider i debatten bli tvunget til å forsvare synspunkter de egentlig ikke står inne for. De føler at de må velge side.

Det er også slik at når man velger å fremme bastante standpunkter for eksempel at "barn aldri lyver", vil dette gjerne gi grunnlag for en motreaksjon, der motparten fremmer det motsatte standpunktet - "barn lyver om seksuelle overgrep”. Dersom motpartens synspunkter får stor gjennomslagskraft, mislykkes man i forsøket på å gyldiggjøre kunnskap. Forsøket på å gyldiggjøre kunnskapen om seksuelle overgrep mot barn, fører isteden til ugyldiggjøring ved at oppfatningen av at barn lyver blir tillagt større vekt. Her ligger noe av det skremmende i de motstridende kreftene som feltet preges av. Psykologen Ruth Toverud har pekt på dette. Hun skriver at:

\footnotetext{
"Kunnskapens sykliske tilsynekomst i vårt fagfelt og drøftingene av de motstridende tendenser i kulturen peker henimot at vi selv deltar i tabuisering og taushetsbelegging, selv når vi vil og kanskje tror at vi holder på med det motsatte." (1998 s. 43).
}

Den andre motpolen i debatten er de som fremmer ensidige og stereotype oppfatninger som et forsvar mot en såkalt moralsk panikk ${ }^{2}$. I så fall fungerer stereotypiene som forståelser som har til hensikt å motvirke moralske panikker.

I følge Thomas Mathiesen (1986), er det tre sentrale kjennetegn ved moralske panikker. For det første retter moralske panikker seg mot noen som står svakt i samfunnets maktstrukturer. For det andre vil en moralsk panikk rette seg mot noe som utfordrer det rådende moralsystem. For det tredje retter den seg mot noen som egner seg til å fremstå som syndebukker. Balvig (1999) trekker frem andre sentrale kjennetegn ved moralske panikker. Et av disse er en økning i fiendtlige og utpregede negative holdninger mot grupper eller fenomener som fremstilles som farlige og skadelige, og hvor det foreligger en klar klassifikasjon - altså et klart skille mellom dem og oss (Balvig 1999 s. 51). En stereotypi representerer en klar klassifikasjon - for eksempel forestillingen om den pedofile overgriperen. Stereotype forståelser er da også et kjennetegn som trekkes frem ved moralske panikker.

Flere hevder at det hersker en moralsk panikk rundt seksuelle overgrep mot barn. I norsk og nordisk sammenheng er kanskje Jan Brøgger og Berl Kutchinsky av de mest kjente representantene for dette synet (se Brøgger 1990 og Kutchinsky 1992a og 1992b). Flere av de som fremhever at feltet seksuelle overgrep mot barn har vært preget av en moralsk panikk, trekker paralleller til hekseprosessene som pågikk i Europa i perioden fra 1400 til 1600-tallet (se Goode \& Ben-Yehuda 1994 s. 150-151, Brøgger 1990 s. 310). Perioden da hekseprosessene pågikk var preget av mistenkeliggjøring, anklager, "rettssaker" og avstraffing av personer man antok var hekser, eller sto i ledtog med personer 
som drev heksevirksomhet. Når anklagen først var fremmet, hadde den anklagede personen lite å stille opp med for å unngå anklagens grufulle konsekvenser (jfr. Goode \& Ben-Yehuda 1994 s. 150-151). Et fellestrekk som trekkes frem mellom hekseprosessene og den såkalte panikken på feltet seksuelle overgrep mot barn, er at det i begge tilfeller har vært en eksplosjonsartet frykt og bekymring knyttet til noe som ble oppfattet som svært truende for allmennheten.

Blant de som argumenterer for at det har vært en moralsk panikk på feltet seksuelle overgrep mot barn, finner en de en kan kalle representanter for et kritisk perspektiv på seksuelle overgrep mot barn. Det er særlig tre fokus representanter for dette synet fremhever som sentrale: For det første fremheves det at det rapporterte omfanget av seksuelle overgrep mot barn er overdrevent. For det andre stiller de seg kritiske til psykologenes rolle på feltet. Det fremheves at psykologer overfortolker tegn og symptomer i retning av seksuelle overgrep uten at det er vitenskapelig grunnlag for et slikt standpunkt. Den svenske vitnepsykologen Astrid Holgerson skriver for eksempel at:

\footnotetext{
"Psykologer, psykiatere og sosiologer har bidratt til at man ut i fra terapeutiske utgangspunkter og ensidig materiale, eller ut i fra ren rykteinformasjon, sprer ubegrunnede generelle påstander. Det kan for eksempel handle om tegn på incest og seksuelle overgrep, om forekomsten av daghjemsovergrep og rituelle overgrep, om "kroppserindringer", om barns såkalte traumatiske erindringer og manipulative metoder for å få barn til "å fortelle" (1997 s. 101).
}

Det tredje argumentet som ofte fremheves er at seksuelle overgrep mot barn ikke har så store skadevirkninger som psykologer og psykiatere hevder at det har. I sin argumentasjon trekker representantene for dette synet også frem forestillingen av mødre som leverer falske anmeldelser, psykologer som "planter" falske overgrepminner i pasientene, og overivrige barnevernsarbeidere som ser overgrep overalt. Med andre ord kritiserer de premissene for at fenomenet seksuelle overgrep mot barn har fått den oppmerksomheten som det har fătt. Gjennom argumentene som representantene for dette synet trekker frem, er også disse med å gjøre seksuelle overgrep mot barn til et felt preget av stereotype og ensidige forståelser. På denne måten utgjør disse den andre motpolen som er med å forsterke kontroversene på feltet. Man kan også tenke seg at representantene for dette synet hadde vært mer nyanserte i sin argumentasjon dersom debatten generelt hadde vært mer nyansert.

De overnevnte motpolene kan karakteriseres som ytterpunkter i debatten. Disse to motpolene skaper bølger som er med å forsterke uttrykkene på feltet. Der representantene for det kritiske perspektivet hevder at barn lyver om seksuelle overgrep, hevder de som ønsker å bekjempe denne motstanden at barn aldri lyver om seksuelle overgrep. Det blir en konkurranse om hvem som skal ha definisjonsmakten på feltet. Mange vil fremholde at sannheten befinner seg et eller annet sted mellom disse ytterpunktene. Nøyaktig hvor skal ikke jeg ta stil- 
ling til, men det man med sikkerhet kan slå fast er at ingen av stereotypiene "barn lyver aldri" eller "barn lyver bestandig" er sanne. Dette vet antagelig også de som fremholder de stereotype oppfatningene, eller iallfall noen av dem. Noe av årsaken til at slike synspunkter likevel fremholdes, kan altså være at det ligger noe selvforsterkende i debatten på feltet.

Et fellestrekk ved alle forklaringene jeg har trukket frem, er at de stereotype forståelsene er uttrykk for et forsvar mot ulike sider ved feltet seksuelle overgrep mot barn. Forsvaret har rettet seg mot ubehaglig kunnskap, mot farlig kunnskap eller mot motstanderens argumenter i debatten. På denne måten kan stereotypiene på fagfeltet og i samfunnsdebatten sees som uttrykk for samfunnsmessige forsvarsmekanismer.

\section{Mulige konsekvenser av stereotype oppfatninger på feltet}

Forståelsen av hvorfor feltet er preget av slike oppfatninger, kan ha betydning for hvordan vi ser på personene som er involvert i saker om seksuelle overgrep mot barn, og for hvilke handlingsalternativer som velges for å håndtere problemet. Oppfatningen av barn som løgnaktige kan ha betydning for om barn blir trodd når de forteller om seksuelle overgrep. At mødre fremmer falske påstander om seksuelle overgrep, kan skape en sterk mistro til mødre som melder fra om en mulig overgrepmistanke. Oppfatningen av et barnevern som er overivrig i tjenesten, kan videre føre til at barnevernet blir tilbakeholdne med å gripe inn i saker hvor det er grunn til å mistenke seksuelle overgrep.

Stereotypiene kan videre ha betydning for selvforståelsen til de personene som er involvert. Oppfatningen av barn som løgnaktige kan forsterke den redselen og tilbakeholdenheten mange ofre for seksuelle overgrep gir uttrykk for når de forteller om overgrepopplevelser. Oppfatningen av overgripere som pedofile kan også gjøre det vanskelig for personer som har begått seksuelle overgrep å se muligheter for endring, da overgrepene blir definert som et resultat av vedkommendes avvikende personlighet.

Ensidigheten og stereotypiene kan også ha betydning i forhold til forebyggelse av seksuelle overgrep mot barn. Forståelsene kan føre til at fokus rettes bort fra sentrale overgreptyper. For eksempel har man tidligere sett at motstanden mot å se seksuelle overgrep mot barn og da særlig incest, har ført til en endret forståelse av hvilke typer overgrep barn utsettes for. Den almene forståelsen har skiftet fra å forholde seg til incestovergrep, til i stedet å oppfatte seksuelle overgrep som noe som først og fremst finner sted utenfor familien (Olafson, Corwin og Summit 1993). Når fokus plasseres utenfor familien, blir det lite nærliggende å stille spørsmål om det er forhold ved vår kjønnskultur som er med å underbygge at barn utsettes for seksuelle overgrep. For eksempel kan fokuseringen av den pedofile overgriperen være med å rette hovedfokus mot seksuelle overgrep begått av noen utenfor familien. Dersom endringer i kjønnskulturen er en vesentlig forutsetning for å forhindre at barn utsettes for seksuel- 
le overgrep, kan dette forhindre oss i å komme lenger i å forebygge seksuelle overgrep mot barn.

Ensidigheten og stereotypiene kan også ha betydning for hvilke handlingsalternativer man velger i forhold til seksuelle overgrep mot barn. Dersom man for eksempel oppfatter personer som begår seksuelle overgrep som slaver av sine egne drifter, kan dette gi grunnlag for å iverksette repressive tiltak. Dette kan ha samfunnsmessige konsekvenser. For eksempel kan en tenke seg at behovet for overvåkning av pedofile kan brukes som en spydspiss i forbindelse med utvidede muligheter til elektronisk overvåkning. Når et slikt tiltak først er tatt i bruk i forhold til én type lovbrudd, risikerer man at slik overvåkning tas i bruk i forhold til andre typer lovbrudd. På denne måten kan stereotypiene faktisk få betydning for bruk av ulike kontrolltiltak i samfunnet. Samtidig vil en slik utvikling bringe fokus bort fra mer sivile og behandlingsorienterte løsninger som ikke nødvendigvis involverer samfunnets kontrollapparat.

Et spørsmål som har vært reist av flere er også om de sterke kontroversene på feltet, som ligger til grunn for de stereotype og ensidige forestillingene, kan føre til at seksuelle overgrep mot barn, og da først og fremst incest, igjen forsvinner fra den offentlige arena. Dette ville $\mathrm{i}$ så fall representere et stort tilbakeskritt og ha alvorlige konsekvenser for de barna som utsettes for seksuelle overgrep. Det fremholdes imidlertid noen steder at en slik utvikling kanskje er mindre sannsynlig i dag fordi fokuseringen av seksuelle overgrep mot barn i løpet av de siste 20 årene har ført til at feltet som sådan i større grad er blitt en integrert del av samfunnsapparatet:

“Kunnskap om seksuelle overgrep og virkningene av dem er ønsket, men den kulturelle til-
latelsen og ønsket om denne kunnskapen er ikke entydig. ̊̊ være bærer av slik kunnskap
kan innebære en kulturelt risikofylt posisjon. Det synes vanskelig å gjøre seg opp noen klar
mening om hvorvidt tiden er moden for at kunnskap om seksuelle overgrep mot barn vil ha
noen varig plass i vår kulturelle bevissthet. De "kulturelle vinder" blåser i flere retninger,
og det kan variere nokså kjapt hva som ser ut til å være hovedretningen. Men kanskje er det
langt flere nå enn tidligere som vet nok til at de ikke vil og kan glemme.” (Toverud $1998 \mathrm{~s}$.
43).

Noter

Karin Widerberg (1995) problematiserer det å se seksuell trakassering som "et fenomen". I dette ligger en forståelse av virkeligheten som noe avgrenset og tellbart. Seksuell trakassering må ifølge Widerberg istedet forstås som "relation, process och kultur" (1995 s. 85). Denne innvendingen har samme gyldighet i forhold til seksuelle overgrep mot barn. At jeg bruker betegnelsen "fenomen" er rett og slett i mangel av et bedre kortfattet begrep.

2 Jeg stiller meg kritisk til betegnelsen moralsk panikk, slik noen bruker det på feltet seksuelle overgrep mot barn, fordi panikkbegrepet ikke bare rammer omfanget, men også selve kjernen i fenomenet. Panikkbegrepet er dermed egnet til å diskvalifisere overgrep og virkelighetsforståelser hos personer som faktisk har vært utsatt for seksuelle overgrep. 


\section{Litteratur}

Bergenheim, Åsa (1998): Kan ej för otukt fällas. Om vetenskapens och det svenske rättsväsendets förhållningssätt till incest och sexuella övergrepp mot barn i perioden 1850-1910. Umeå: Umeå universitetet.

Brøgger, Jan (1990): "Incest og moralsk panikk". I: Nytt norsk tidsskrift s. 307-314.

Balvig, Flemming (1999): "Den kriminologiske forskning og kriminalpolitikken" I: Vilkårene i den retspolitiske debat ret og etik-kundskab og magt. (Flemming Balvig og Jørn Vestergaard red.) København: Kriminalistisk Skriftserie nr. 5.

DSM-III (1986): Psykiatriske diagnoser. Kategorier og kriterier i følge DSM-III. Oslo:Paul Moxnes Forlag.

Finkelhor, David (1994): “The 'backlash' and the future of child protection advocacy". I: The Backlash. Child protection under fire. (John E. B. Myers ed.) Thousand Oaks: SAGE Publications.

Goode, Erich og Nachman Ben-Yehuda (1994): "Moral panics: Culture, politics and social construction." I: Annual Review of Sociology s. 149-171.

Hallberg, Margareta og Eva Marie Rigné (1999): En studie av debatten om sexuella övergrepp mot barn 1994-1998. Stockholm: Socialstyrelsen.

Hennum, Ragnhild (1999): Bevis i saker om seksuelle overgrep mot barn. Avhandling for dr. philosgraden. Oslo: Universitetet i Oslo.

Holgerson, Astrid (1997): "Psykologien og rettssikkerheten.” I: Seksuelle overgrep mot barn - et kritisk perspektiv. Oslo: Fagbokforlaget.

Holter, Harriet (1992): "Tvang til voksen seksualitet. Om seksuelle overgrep mot barn." I: Nytt om kvinneforskning s. 24-33.

Høigård, Cecilie (1996): "Lemlesting av mennesker i det godes tjeneste." I: Aftenposten. 11. september. Kronikk.

Kutchinsky, Berl (1992a): “The child sexual abuse panic.” I: Nordisk Sexologi s. 30-42.

Kutchinsky, Berl (1992b): "Et dilemma og forslag til en løsning". I: Dansk Psykolognyt s. 434-435.

Leira, Halldis (1992): "Fra tabuisert traume til anerkjennelse og erkjennelse." I: Nytt om kvinneforskning s. 59-67.

Mathiesen, Thomas (1986): Om moralske panikker. Et eksempel og en tolkning. Bergen: Institutt for massekommunikasjon.

Mossige, Svein (1998): Har barnet mitt vart utsatt for seksuelle overgrep?: en narrativ analyse av mødres fortellinger. Avhandling for dr. psychol-graden. NOVA-rapport 21. Oslo:NOVA

Myers, John E.B. (1994): "Definition and Origins of the Backlash Against Child Protection.” I: The Backlash. Child protection under fire. (John E. B. Myers ed.) Thousand Oaks: SAGE Publications.

Nielsen, Beth Grothe (1992): "Seksuelle overgreb mod børn. Tre strafferetlige dogmer." I: Nordisk Sexologi s. 92-104.

Olafson Erna, David Corwin og Roland C. Summit (1993): "Modern history of child sexual abuse awareness: cycles of discovery and suppression." I: Child Abuse \& Neglect s. 7-24.

Skiaker, Hanne Kolterud (1998): Massemedia og moralsk panikk. Mellomfagsavhandling i kriminologi. Oslo: Univesitetet i Oslo.

Toverud, Ruth (1998): Barn, terapi og seksuelle overgrep. En studie av psykoterapeuters beretninger: Oslo: Tano Aschehoug.

Widerberg, Karin (1995): “Oppsummerende synspunkter: Seksualisert vold - virkelighet, forskning og politikk." I: Seksualisert vold og rettsvesenet. Rapport fra konferanse 13. oktober 1995.

\section{Adresse: Barne- og familiedepartementet}

Postboks 8036 Dep.

N - 0030 Oslo 